\title{
Effect of accidental factors on rooting of Malus Golden Delicious
}

\author{
CJM Denissen, GJ De Klerk, MRJ Albers, J Ter Brugge, BPAM Kunneman
}

Centre for Plant Tissue Culture Research (COWT), PO Box 85, 2160 AB Lisse, The Netherlands

(COST Meeting, 21-23 May 1992, Dijon, France)

\begin{abstract}
Summary - in Malus 'Golden Delicious', large fluctuations may occur in rooting from one subculture to another. This may be caused by various accidental external factors. Some of these factors have been examined. However, even though they were varied over a wide range, they had no significant effect on rooting, indicating that they were not the cause of the fluctuations. In the 3 successive subculture cycles examined, the rooting percentage and number of roots showed only small but significant differences. Accuracy in medium preparation had no significant effect, but location in the growth chamber, storage of the medium, and the individual researcher did: medium stored for 6 or $12 \mathrm{wk}$ at $4{ }^{\circ} \mathrm{C}$ gave better rooting than fresh medium; one of the 4 researchers always had the best rooting results. This was possibly caused by more careful selection of shoots for rooting.
\end{abstract}

Résumé - Effets de facteurs accidentels sur l'enracinement de Malus Golden Delicious. Chez Malus Golden Delicious, on peut observer des variations importantes dans l'enracinement d'une subculture à une autre. Cela peut être dû à divers facteurs externes accidentels. Nous avons examiné certains de ces facteurs. Mais, malgré une large variation de leur intensité, ils n'ont pas eu d'effet sur l'enracinement ce qui indique que ce ne sont pas eux qui sont à la source de ces variations. Au cours des 3 cycles de subculture que nous avons examinés, le pourcentage d'enracinement et le nombre de racines ont manifesté des différences faibles mais significatives. La précision dans la fabrication des milieux n'a pas d'effet, mais la position dans la chambre de culture, la conservation du milieu et l'opérateur en ont eu. Un milieu conservé 6 ou 12 semaines à $4^{\circ} \mathrm{C}$ donne un meilleur enracinement que le même milieu frais. Un des 4 opérateurs a tuujours eu de meilleurs résultats. Ceci vient peut-être d'une meilleure sélection des tiges pour l'enracinement.

\section{INTRODUCTION}

Well established cultures often show large fluctuations in rooting from one subculture to another, even though all conditions seem to be similar. These fluctuations may be due to systematic or accidental differences between successive rooting trials. In the present study we examined the effects of some accidental external factors on rooting in Malus.

\section{MATERIALS AND METHODS}

An established culture of Malus 'Golden Delicious' (used as model plant in the COST 87 working group 'Malus' and distributed by P Druart, Gembloux, Bel- gium) was maintained in 6-wk-subculture cycles at $20^{\circ} \mathrm{C}$ (daylength $16 \mathrm{~h}$, light intensity 30 E. $\mathrm{m}^{-2} \cdot \mathrm{s}^{-1}$ ). The culture had been subcultured $>50$ times. The conditions during propagation and rooting were as described by De Klerk et al (1990). Shoots $1-2 \mathrm{~cm}$ in length were used for rooting. For the shoots used in this experiment, all handling during the multiplication was carried out by the same person.

The effects of 4 factors were studied: 1) accuracy in preparing the culture medium; 2) storage of the medium; 3) the researcher; and 4) location in the growth chamber.

\section{Accuracy in preparing the culture medium}

The medium was prepared with 1-4-month-old stock solutions in full light (ie no particular care was given to its preparation). It should be noted that one of the me- 
dium components, riboflavin, is very photolabile and catalyzes the photodegradation of indole-3-butyric acid (IBA) (Gorst et al, 1983). The $\mathrm{pH}$ was adjusted after adding riboflavin, proline and IBA, but before adding the agar. The medium was left in the hot autoclave after autoclaving for an additional $30 \mathrm{~min}$.

For the 2nd preparation, the medium was prepared accurately with fresh stock solutions and kept away from the light. Riboflavin, proline and IBA were added after adjusting the $\mathrm{pH}$ and after adding and dissolving the agar at $90^{\circ} \mathrm{C}$. The medium was autoclaved for exactly $15 \mathrm{~min}$ and stored immediately after forced cooling.

\section{Storage of the medium}

The medium was used after $1 \mathrm{~d}$ or stored in the dark at $4{ }^{\circ} \mathrm{C}$. The stored medium was used only in the 2 nd cycle (6 wk storage) and 3rd cycle (12 wk storage).

\section{The researcher}

Four individuals - A, B, C and D - harvested shoots and transferred them to rooting medium.

\section{Location in the growth chamber}

Three locations in the growth chamber differing in distance from the air-conditioning equipment were tested. Location 3 was the closest, location 1 the most distant and location 2 was at an intermediate distance.

In 3 successive subculture cycles, 20 shoots were rooted with $0.2 \mathrm{mg} \mathrm{l}^{-1}$ IBA for each treatment. Thus the total number of shoots used was 2400 : 480 for the 1st cycle and 960 for the 2nd and 3rd cycle. Rooting was scored after $4 \mathrm{wk}$, both as rooting percentage and as mean number of roots per rooted shoot. To test the significance of the effect of the 4 factors, an analysis of variance was carried out for the 2 nd and 3rd cycle together: For percentage rooting, an angular transformation was applied $(x=(180 / \pi) \arcsin$ (percentage/100) $)^{1 / 2}$.

\section{RESULTS}

During the period 1989-1991, we observed wide fluctuations in the rooting percentage of Malus 'Golden Delicious' between successive rooting trials (fig 1). Between the 3 cycles in which the various accidental factors were examined, small but significant fluctuations in rooting percentage and number of roots were found (table I). The rooting percentages in the 2 nd and 3 rd cycle dif- fered significantly. The number of roots was significantly different in all 3 cycles.

Accuracy in medium preparation had no significant effect on rooting (table II). Regarding location in the growth chamber, no significant effect on the rooting percentage was found. The number of roots per rooted shoot in location 1 was significantly lower than in locations 2 and 3.

The percentage of rooting and the number of roots per shoot were significantly influenced both by storage of the medium and by the individual researcher transplanting the shoots. Stored medium gave a higher percentage of rooting and a higher number of roots per shoot in comparison with fresh medium. There was no difference in rooting between storage for 6 or 12 wk. Researcher $A$ had better rooting results than the other persons.

For the number of roots per shoot there was an interaction $(P=0.013)$ between the cycle, storage of the medium and the individual transplanting the shoots (fig 2). The fresh medium in the 2nd cycle had the lowest number of roots per shoot and in this case researcher $A$ did not have the best results. With the other persons, differences in results were variable: for example in the 3rd cycle, on fresh medium researcher $C$ and, in the 2nd cycle, on stored medium researcher $D$ had a significantly lower number of roots per shoot than the other individuals.

\section{DISCUSSION AND CONCLUSION}

In this article we report on the effects of accidental factors during the rooting phase. The conditions during multiplication were maintained as constant as possible. In the 3 cycles examined,

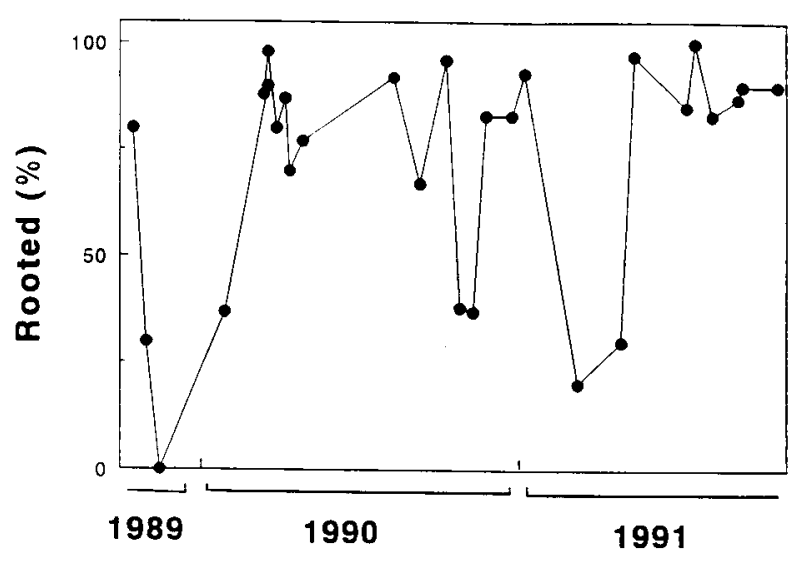

Fig 1. Rooting percentage of Malus 'Golden Delicious' during the period 1989-1991. Each value is derived from a sample of $c a 30$ shoots rooted under standard conditions. 
Table I. Percentage of rooting and number of roots per rooted shoot in 3 successive subculture cycles of Malus 'Golden Delicious' microcuttings.

\begin{tabular}{lll}
\hline Cycle & Percentage & No of roots \\
\hline 1 & $85.4^{\mathrm{ab}}$ & $4.81^{\mathrm{a}}$ \\
2 & $83.0^{\mathrm{a}}$ & $4.30^{\mathrm{b}}$ \\
3 & $86.8^{\mathrm{b}}$ & $4.45^{\mathrm{c}}$
\end{tabular}

Values indicated by different characters are significantly different at $P$ $<0.01$; " Values are significantly different at $P<0.001$.

factors that are generally not taken into account were analysed. We observed only small (but statistically significant) variations. This indicates that variation in these factors is unlikely to have caused the large fluctuations shown in figure 1.

Of the various factors, the researcher transplanting the shoots and storage of medium were

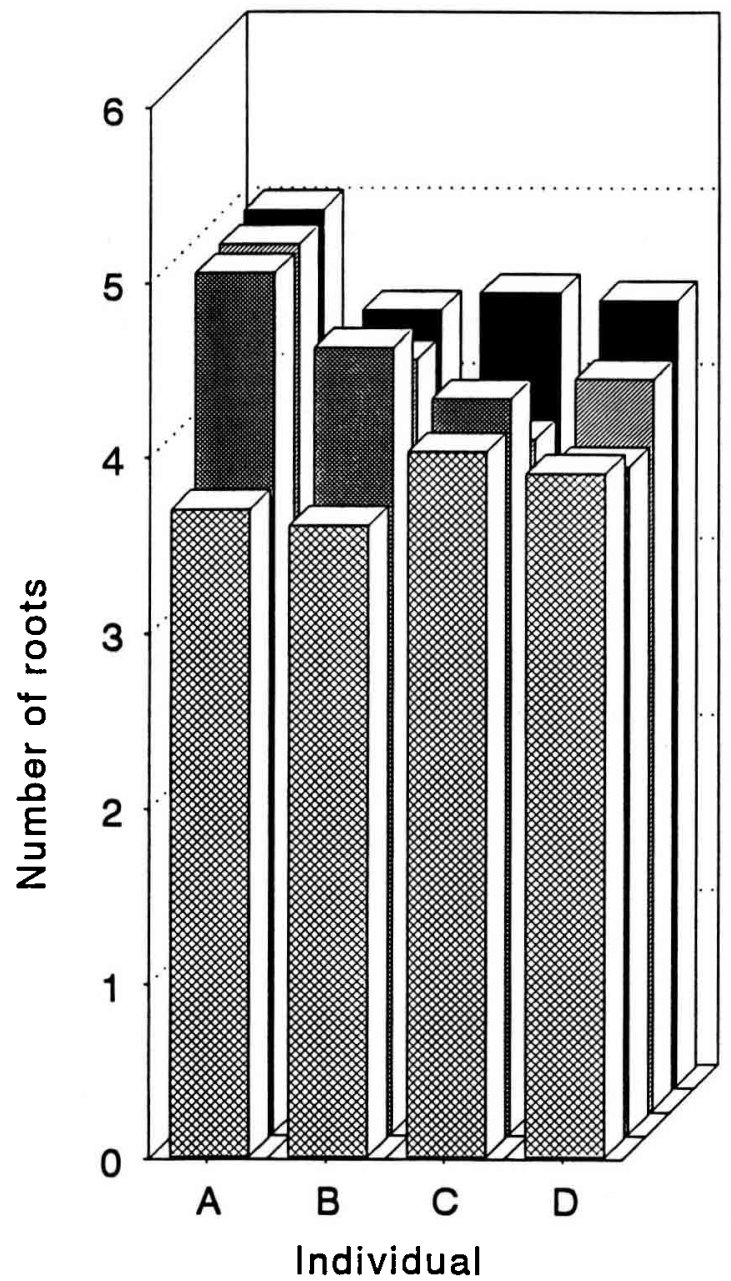

Fig 2. Number of roots per rooted shoot in Malus 'Golden Delicious' microcuttings. The effect of storage of medium ( $\mathrm{fr}=$ fresh and st $=$ stored) and individual researcher $(A, B, C$ and D) transferring the shoots are shown for the 2nd and 3rd subculture cycle $(\mathrm{ccl} \mathrm{2,} \mathrm{cll} 3)$ of the present experiment; $\mathbb{Z} \mathrm{fr} \mathrm{ccl}$ 2; st $\mathrm{ccl} 2 ; \mathbb{Z} \mathrm{fr} \mathrm{ccl} 3 ; \mathrm{st} \mathrm{ccl} 3$.
Table II. Percentage of rooting and No of roots per rooted shoot in Malus 'Golden Delicious' microcuttings. The effects of accuracy in medium preparation, medium storage, individual researcher and location in the growth room were examined (data of the 2nd and 3rd cycle).

\begin{tabular}{lll}
\hline Factor & Percentage & No of roots \\
& & \\
\hline Accurary & & \\
Non-accurate & 84.0 & 4.23 \\
Accurate & 85.7 & 4.30 \\
Storage & & \\
Fresh & $82.3^{\mathrm{a}}$ & $4.05^{\mathrm{a}}$ \\
Stored & $87.5^{\mathrm{b}}$ & $4.48^{\mathrm{b}}$ \\
Individual & & \\
A & & $4.63^{\mathrm{a}}$ \\
B & $94.4^{\mathrm{a}}$ & $4.20^{\mathrm{b}}$ \\
C & $80.2^{\mathrm{b}}$ & $4.14^{\mathrm{b}}$ \\
D & $84.2^{\mathrm{b}}$ & $4.09^{\mathrm{b}}$ \\
Location & $80.8^{\mathrm{b}}$ & \\
1 & & $4.03^{\mathrm{a}}$ \\
2 & 84.7 & $4.42^{\mathrm{b}}$ \\
3 & $84.5^{\mathrm{b}}$ & \\
\hline
\end{tabular}

Values indicated by different characters are significantly different at $P$ $<0.01$. Values are significantly different at $P<0.001$.

found to have the most significant effects. An individual's performance is likely to depend on a complex of factors, viz selection of shoots, method of cutting and working speed (ie the time that the shoot is exposed to dry air in the laminar flow hood). In our experiment, selection of shoots was likely the most important factor.

It has been reported that autoclaving may result in the formation of toxic substances from the hydrolysis of carbohydrates (Schenk et al, 1991; Uosukainen, personal communication). Possibly these and/or other toxic compounds are destroyed during the storage of the medium. Chemical changes during storage, ie of $\mathrm{pH}$ and hormones, have been reported by various authors (Stasinopoulos and Hangarter, 1990; Owen et al, 1991). It should be noted, however, that we stored the medium in the dark at $4^{\circ} \mathrm{C}$, and that under these circumstances the changes are small (Stasinopoulos and Hangarter, 1990; Owen et al, 1991). Another possible explanation of the effect of storage is that oxygen, eliminated from the medium by autoclaving, had diffused back into the medium during the protracted storage at low temperature. Thus the lower part of the shoot, where the roots were formed, was under anaerobic conditions in fresh medium and not in stored medium. It is well known that rooting performance is better 
under oxygen-rich conditions (Pierik and Steegmans, 1975).

Rooting may have been influenced by other accidental factors not been examined in this study, for example humidity in the growth chamber. Humidity varied between $68-30 \%$ during the dark period and between $55-30 \%$ during the light period, depending on the outside temperature. High humidity may cause vitrification. Vitrified shoots do not root (De Klerk and Ter Brugge, 1992). Low humidity may lead to water stress and therefore to reduced rooting (Rajagopal and Andersen, 1980).

Another possible explanation for the large fluctuation in rooting is that unidentified systematic factors affect the rooting ability of the shoot. Endogenous development processes possibly occur independently of the subculture cycle. For example, 'dormancy' may be induced which in turn would reduce the rooting capability ( $\mathrm{De}$ Klerk and Ter Brugge, 1992). Alternatively, the shoots may be insufficiently rejuvenated and are between the juvenile and adult phases.

At this stage, we cannot determine which of the afore mentioned factors has the most important effect on rooting.

\section{ACKNOWLEDGMENT}

We thank JHM Sieverink for analysing the data.

\section{REFERENCES}

Gorst JR, Slaytor M, Fossard RA (1983) The effect of indole-3-butyric acid and riboflavin on the morphogenesis of adventitious roots of Eucalyptus ficfolia $\mathrm{F}$ Muell grown in vitro. J Exp Bot 34,1503-1515

De Klerk GJ, Ter Brugge J (1992) Factors affecting adventitious root formation in microcuttings of $\mathrm{Mal}$ us. Agronomie 12, 747-755

De Klerk GJ, ter Brugge J, Smulders R, Benschop M (1990) Basic peroxidases and rooting in microcuttings of Malus. Acta Hortic 280, 29-36

Owen HR, Wengerd D, Miller AR (1991) Culture medium $\mathrm{pH}$ is influenced by basal medium, carbohydrate source, gelling agent, activated charcoal and medium storage method. Plant Cell Rep 10, 583586

Pierik RJM, Steegmans HHM (1975) Analysis of adventitious root formation in isolated stem segments of Rhododendron. Sci Hortic 3, 1-20

Rajagopal V, Andersen AS (1980) Water stress and root formation in pea cuttings. I. Influence of the degree and duration of water stress on stock plants grown under two levels of irradiance. Physiol Plant 48,144-149

Schenk N, Hsiao K-C, Bornman CH (1991) Avoidance of precipitation and carbohydrate breakdown in autoclaved plant tissue culture media. Plant Cell Rep 10,115-119

Stasinopoulos TC, Hangarter RP (1990) Preventing photochemistry in culture media by long-pass light filters alters growth of cultured tissues. Plant Physiol 93,1365-1369 